muscular platforms. The pair of these which occur at the front of the glabella are expanded anteriorly, and are covered with small depressions like those occurring at points of muscular attachment in modern Crustacea. About $0.6 \mathrm{~mm}$. behind these well-marked muscular platforms under the posterior part of the glabella we find another pair that are poorly defined with small raised areas sometimes isolated, irregularly arranged, and not so high as those in front.

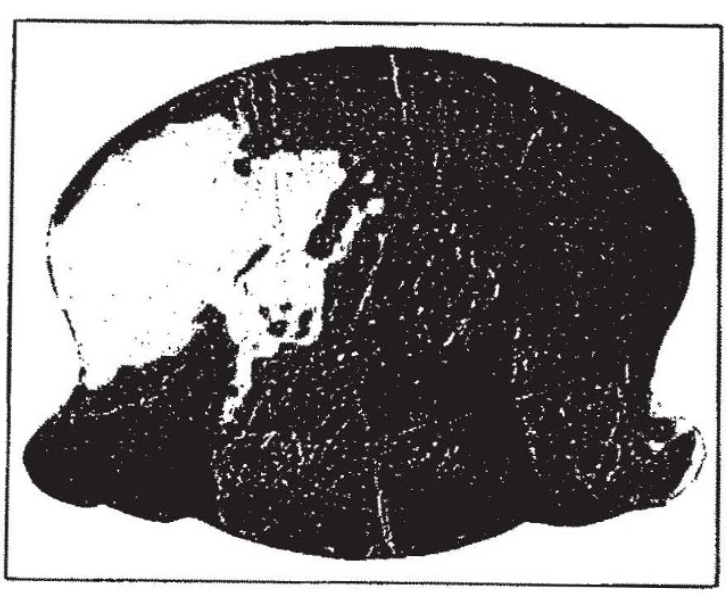

INTERNAY CAST OF MUDDLE-SHIELD OF "Illanus" proles var. shelvensis WHITrARD, SHowivg rMPRESSIONS OF PATRED MUSCLE.PLATFORMS UNDER FRONT PART OF GLABELLA, WITI A PAT OF FAINTER AND LESS REGULAR MUUSCULAR AREAS BEHIND, $\times 1 \frac{2}{3}$.

Birmingham University Geological Museum, Figured Collection T. 215 .

In cranidia areas of muscular insertion havo been previously described by von Volborth and Prof. Öpik. In his Illanus crassicauda var. dalmanni, von Volborth ${ }^{3}$ found four paired areas under tho glabella -the illustration is copied by Salter-and clearly distinguished these from a pair of elongate oval depressions in the axial furrows. None of von Volborth's scars, wo note, is relatively as large as the front pair in ' $I$.' proles var. shelvensis. Under the frontal lobe of the glabella of several species of Chasmops Opik $^{5}$ has discovered small elevations in two rows converging in front and behind, which he regards as points of attachment for the muscles which served to dilate the osophagus.

In explaining the novel musculature of 'Illcemus' proles var. shelvensis, the easiest supposition is that it may have arisen through fusion of muscle impressions like those seen in $I$. crassicauda var. dalmanni, probably three pairs going to the making of the large anterior muscle scars of the Valsall form. This development may have been connected with change in feeding habits, for example, evolution of a sucking mouth, as it is unlikely that an enlarged pair of mandibular appendages ever appeared in the Illænidx.

The genotypo of Illænus is $I$. crassicauda (Wahlen. berg). Von Volborth's variety certainly seems to come close to this. It would, therefore, be justifiable at once to separate ' $I$.' proles var. shelvensis as the representative of a new genus. It has been thought better, however, to delay placing the Shelve and Walsall specimens in a new systematic position, since re-examination of collections of illænids may in the near future give additional information about the condition of cranidial muscle platforms and the possible value of these features in taxonomy.

Department of Geology,

Archre Lajiont.

University, Edgbaston,

Birmingham 15. Juno 14.

1 "On Sllurian and Cambrian Rocks encountered in a Deep Boring at Walsall, South Staffordshire", Geol. Mfag., 74, 241-257 (1937).

" "The Upper Valentlan Trilobite Fauns of Shropshire", Ann. Ifag. Nat. Hist., Ser. 11, 1, 93-94, Pl. II, Figs. 7-8 (1933).

- "Uber die mit glaten Rumpfgliedern versehen russischen Trilobiten, nebst elnem Anhanke iber die Berregungsorgane und über das IIerz derselben", Mem. Imp. Acad. Sci. St.-PeterEbourg, VII Ser., 6, No. 2, 9, 13, 15, Taf. II, Fig. 8 (1863).

"Britlsh Trilobites from the Cambrian, Silurian, and Deronlan Formations", Mon. Palcont. Soc., 192, Fig. $50 B$ (1866).

s "Trilobiten aus Estland", Publ. Geol. Inst. Univ. Tartu, No. 52

Pl. IX, Figs. 1-3, etc (1937).

\section{'Auto-parasitism' by Nemeritis canescens (Grav.) (Ichneumonidæ)}

THERE appears to bo no published record of oviposition by an insect in the body of another of its own species. This interesting phenomenon, however, occurs in Nemeritis canescens (Grav.) (Hymenop. tera: Ichneumonidæ), a parasite of the Mediterranean flour moth (Ephestia kühniella Zeller) in certain circumstances.

Nemeritis canescens breeds parthenogenetically and is ready to oviposit within half an hour after its emergence from the pupa. In a jar containing fully grown host larve, the parasites which dovelop from them do not emerge simultaneously. Those that emerge first $t$ : $y$ to oviposit in those that will emerge in a day or two. The parasite succeeds in laying one or more eggs if its ovipositor pierces the soft ventral side of the abdomen of the imprisoned parasite in the silken cocoon. The egg hatches into a larva which undergoes a part of its dovelopment in the abdomen of its host, which, nevertheless, develops into an imago and may live for some days afterwards.

Experiments corroborated the above observations. Two parasites wero released for six hours in a small jar containing about forty advanced parasito pupx from which the imagines were expected to emerge in a day or two. As each imago emerged, it was at once transferred to a tube and fed on sucrose solution until it died. Twenty-five such parasites were fed in this way, and inside the abdomen of two of them partly developed parasitic larva were found. They were both dead.

In cultures where 80-100 parasites are reared in a jar the percentage is found to be much higher. For batches of 10-20 parasites emerge at intervals of 12-24 hours, and when two batches of about forty parasites have emerged the chance of some of these successfully ovipositing in those that are yet to emerge is high.

Another interesting fact observed was that in Ephestia larvæ, where superparasitism by Nemeritis is a common occurrence, all parasitic larva in one host, except one, die in the first instar. Novertheless, in the abdomen of an adult parasite that was dissected two larvie were found, one well advanced in the third instar and the other in the second instar.

E. S. NARAYANAx.

Department of Zoology and Applied Entomology,

Imperial College of Science and Technology, London, S.W.7. June 9. 